\title{
Reciprocal epigenetic modification of histone H2B occurs in chromatin during apoptosis in vitro and in vivo
}

\author{
K Ajiro ${ }^{1,2}$, AB Scoltock ${ }^{1}$, LK Smith ${ }^{1}$, M Ashasima $^{1,2}$ and JA Cidlowski ${ }^{\star, 1}$
}

Histone H2B phosphorylation at Serine 14 (phosS14) has been proposed as an epigenetic marker of apoptotic cells, whereas acetylation at the adjacent Lysine 15 (acK15) is a property of non-dying cells. We investigated the relationship and the potential regulatory mechanisms between these two epigenetic histone modifications and internucleosomal DNA degradation during apoptosis. Using rat primary thymocytes induced to undergo apoptosis with glucocorticoids we found that H2B phosphorylated at Ser14 was associated with soluble, cleaved DNA in apoptotic nuclei. In contrast acK15 was prevalent in non-apoptotic nuclei and scarce in apoptotic nuclei. This switch between K15 acetylation and S14 phosphorylation on H2B was also observed in apoptotic thymocytes from animals treated in vivo with glucocorticoids and in a rat hepatoma cell line (HTC) induced to die by UV-C or Fas ligand. It is interesting to note that the combined use of a histone deacetylase inhibitor and glucocorticoid suppressed both $\mathrm{S} 14$ phosphorylation and internucleosomal DNA degradation without inhibiting apoptosis in thymocytes. Using synthetic peptides and a PKC phosphorylation assay system, we show that the deacetylation of K15 was necessary to allow the S14 phosphorylation. These findings suggest that selective chromatin post-translational modifications are associated with DNA degradation during apoptosis.

Cell Death and Differentiation (2010) 17, 984-993; doi:10.1038/cdd.2009.199; published online 8 January 2010

A fundamental unit of chromatin is the nucleosome which is composed of two sets of histones $(\mathrm{H} 2 \mathrm{~A}, \mathrm{H} 2 \mathrm{~B}, \mathrm{H} 3$ and $\mathrm{H} 4)$ that are wrapped with 146 base pairs of DNA. ${ }^{1}$ Histones have a tail in the N-terminal domain which is free from DNA and often has various covalent modifications. ${ }^{2}$ In recent studies, it was shown that epigenetic histone modification has an important role in chromatin function leading to the hypothesis that histone modification acts as a 'histone code' possibly for chromatin remodeling. ${ }^{3}$ In most apoptotic cells, internucleosomal degradation is considered a late biochemical hallmark of apoptosis. ${ }^{4,5}$ Previously we demonstrated that histone H2B is phosphorylated in various mammalian apoptotic cells ${ }^{6,7}$ and can be phosphorylated by PKC both in vitro and in vivo. ${ }^{6,8}$ In addition, we determined that the site of the $\mathrm{H} 2 \mathrm{~B}$ phosphorylation is serine 14 (S14) and can involve the action of Mst-1 in vivo. ${ }^{9}$ This $\mathrm{S} 14$ site can also be phosphorylated with PKC- $\delta$ in human $\mathrm{B}$ cells, ${ }^{10}$ and $\mathrm{S} 14$ phosphorylation has been associated with apoptosis ${ }^{9}$ and with DNA double strand breaks. ${ }^{11}$ However, the mechanisms regulating H2B phosphorylation at S14, particularly during apoptosis, are unknown.

Histone $\mathrm{H} 2 \mathrm{~B}$ has also been reported to be acetylated at the $\mathrm{K} 5, \mathrm{~K} 12, \mathrm{~K} 15$ and $\mathrm{K} 20$ sites $^{12}$ which could potentially regulate the phosphorylation of $\mathrm{S} 14$ in the $\mathrm{N}$-terminus of $\mathrm{H} 2 \mathrm{~B}$. For example, it has been recently shown that phosphorylation of $\mathrm{S} 10$ in the yeast histone $\mathrm{H} 2 \mathrm{~B}$, homologous to $\mathrm{S} 14$ in mammals, was regulated by $\mathrm{K} 11$ acetylation. ${ }^{13,14}$ To examine this question in mammalian cells we employed rat primary thymocytes induced by glucocorticoids to undergo apoptosis; a system used for both in vivo and in vitro analysis of apoptotic signal transduction. ${ }^{15-17}$ We previously found that histone H2B was phosphorylated during the induction of apoptosis. ${ }^{6}$ In this report, we examined the regulatory mechanism of the apoptosis-specific $\mathrm{S} 14 \mathrm{H} 2 \mathrm{~B}$ phosphorylation in relation to internucleosomal DNA degradation and deacetylation of the K15 lysine.

\section{Results}

Glucocorticoids induce apoptosis in thymocytes. The induction of thymocyte apoptosis by dexamethasone was initially analyzed by flow cytometry (Figure 1A). Thymocytes treated with $1 \mu \mathrm{M}$ dexamethasone for $4 \mathrm{~h}$ contain a population of cells showing reduced forward-scatter light but increased side-scatter light. This occurrence of a shrunken, granular population of cells is characteristic of programmed cell death (Figure 1A, d). In contrast, this cell

${ }^{1}$ Laboratory of Signal Transduction, National Institute of Environmental Health Science, National Institutes of Health, 111 Alexander Drive, Research Triangle Park, NC, USA

*Corresponding author: JA Cidlowski, Lab. of Signal Transduction, National Institute of Environmental Health Science, National Institutes of Health. 111 TW Alexander Drive, Research Triangle Park, NC 27709, USA. Tel: + 919541 1564, Fax: + 919541 1367; E-mail: cidlows1@ niehs.nih.gov

${ }^{2}$ Current address: National Institute of Advanced Industrial Science and Technology (AIST), Tsukuba, Japan

Keywords: chromatin structure; lymphocyte apoptosis; histone modification; glucocorticoid

Abbreviations: acK15, adjacent Lysine 15; At, attached to a glass substratum; Dt, detached floating in the medium; HTC, hepatoma cell line; HMW, high molecular weight; phosS14, phosphorylation at Serine 14

Received 13.3.09; revised 18.11.09; accepted 19.11.09; Edited by S Nagata; published online 08.1.10 


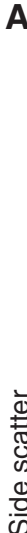
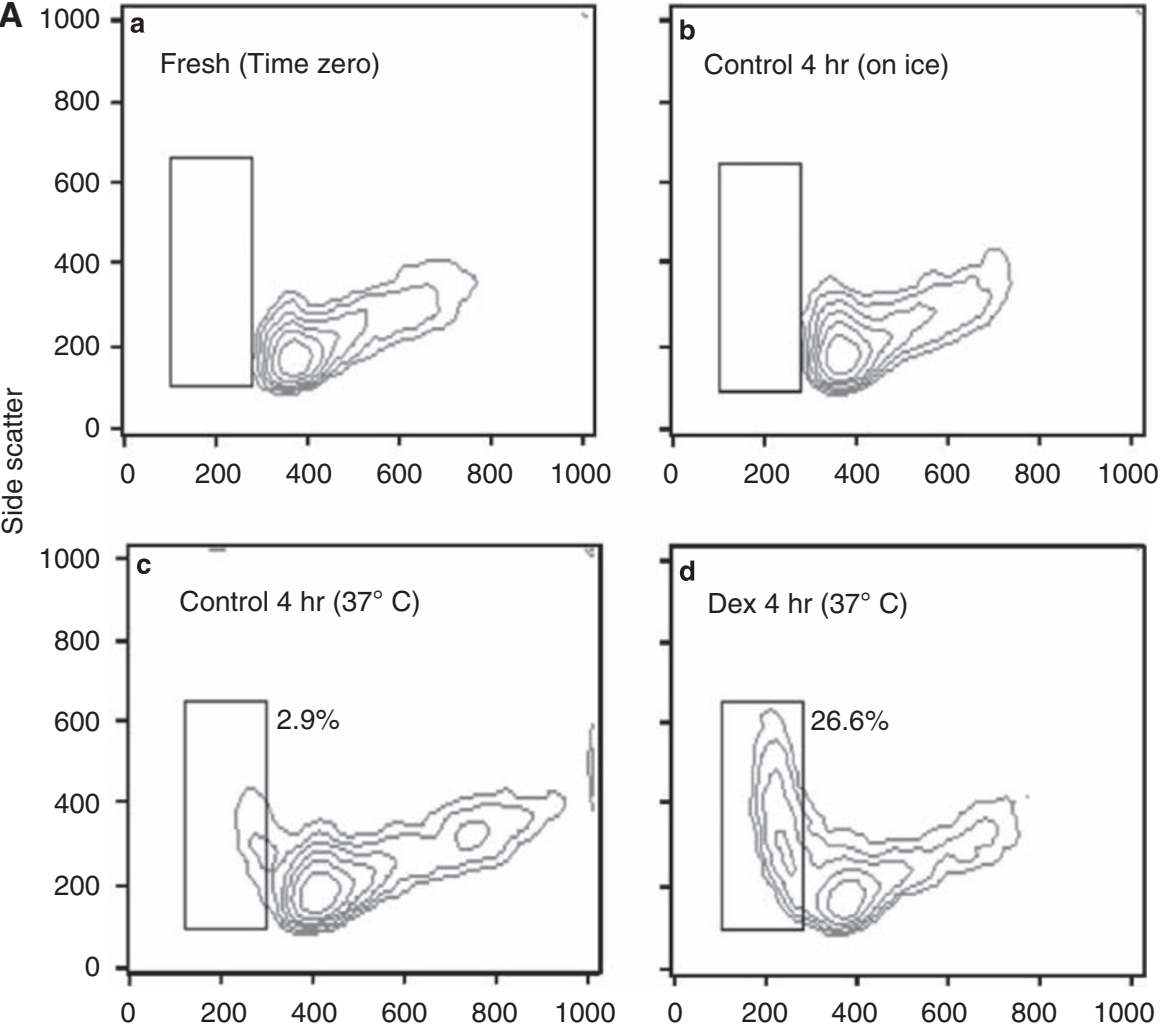

Forward Scatter

B
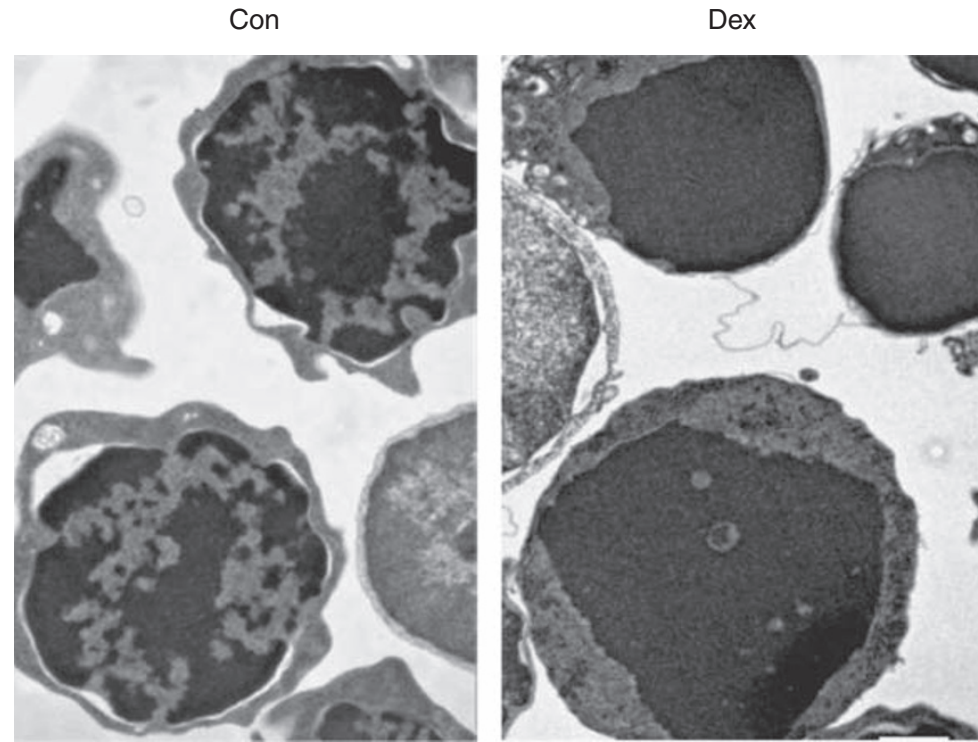
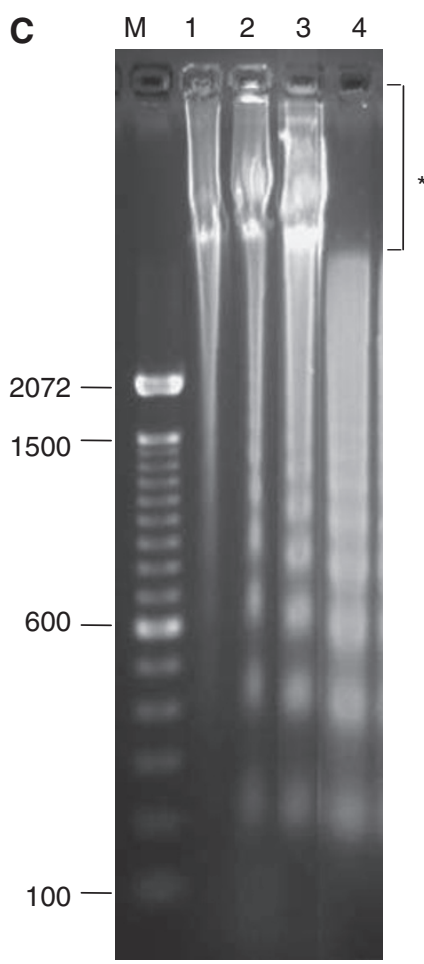

Figure 1 Dexamethasone induces apoptosis in thymocytes. (A) Rat primary thymocytes induced to undergo apoptosis by glucocorticoid treatment. Thymocytes were incubated with $1 \mu \mathrm{M}$ dexamethasone in RPMI 1640 medium for $4 \mathrm{~h}$ at $37^{\circ} \mathrm{C}$ and analyzed by flow cytometry. $X$-axis, forward-scatter indicating cell size. $Y$-axis, side-scatter indicating cell granularity. Apoptotic cells show a decrease in cell size (forward scatter light) with a concomitant increase in granularity (side scatter light). Dexamethasone treatment increases the percentage of apoptotic cells (box). (a) Freshly isolated thymocytes, (b) untreated thymocytes incubated on ice for $4 \mathrm{~h}$, (c) untreated thymocytes incubated at $37^{\circ} \mathrm{C}$ for $4 \mathrm{~h}$ and (d) dexamethasone-treated thymocytes at $37^{\circ} \mathrm{C}$ for $4 \mathrm{~h}$. (B) Electron microscopic observation of apoptotic thymocytes. Thymocytes treated with dexamethasone were fixed as described in the Materials and Methods section. Con, Control thymocytes. Dex, Dexamethasone. Nuclear materials of apoptotic cells are degraded. Magnification: $\times 9, \times 900$. (C) Analysis of DNA fragments from whole or soluble chromatin. Thymocytes treated with dexamethasone were harvested after $4 \mathrm{~h}$. The DNA $(1 \mu \mathrm{g})$ was run on $1.8 \%$ agarose gel and stained with ethidium bromide. Lane 1: freshly isolated DNA from nuclei, lane 2: Control nuclei incubated $4 \mathrm{~h}$, lane 3: nuclei from $1 \mu \mathrm{M}$ dexamethasone-treated nuclei for $4 \mathrm{~h}$, lane 4: DNA from soluble chromatin from nuclei of the dexamethasone-treated cells. Marker DNA; $100 \mathrm{bp}$ DNA ladder. Note: DNA of soluble chromatin (lane 4) does not have high molecular weight (HMW) DNA as indicated by * 
population develops only to a small extent (2.9 versus $26.6 \%$ in Dex treated) in the non-glucocorticoid-treated control cells incubated at $37^{\circ} \mathrm{C}$ and is not detected in freshly isolated cells or cells incubated on ice for $4 \mathrm{~h}$. This $2.9 \%$ of cells seen in our control sample likely reflects spontaneous apoptosis of these cells in culture (Figure 1A, c). Ultrastructural analysis of thymocytes by electron microscopy shows distinct areas of euchromatin and heterochromatin (light and dark staining, respectively) in the nuclei of control thymocytes (Figure 1B, left) in contrast to apoptotic cells, wherein nuclear components appear degraded and showed homogeneous dark staining (Figure 1B, right). Analysis of DNA by agarose gel electrophoresis (Figure 1C) shows the characteristic pattern of internucleosomal DNA cleavage in nuclei from apoptotic thymocytes. After $4 \mathrm{~h}$ incubation of thymocytes with dexamethasone, only lower molecular weight DNA was observed in the soluble chromatin fraction (Figure 1C, lane 4). Together these observations indicate that glucocorticoid treatment for $4 \mathrm{~h}$ is sufficient to induce classic apoptotic DNA fragments in rat thymocytes.

Phosphorylated histone H2B at S14 is abundant in the soluble chromatin. Degraded DNA fragments with their associated histones are separable from whole genomic DNA based on their solubility in non-ionic detergent. Soluble chromatin from thymocytes exposed to $4 \mathrm{~h}$ of $1 \mu \mathrm{M}$ dexamethasone was analyzed by SDS gel electrophoresis (Figure 2a). The relative amount of histones $\mathrm{H} 1, \mathrm{H} 2 \mathrm{~A}, \mathrm{H} 2 \mathrm{~B}$, $\mathrm{H} 3$ and $\mathrm{H} 4$ present in the soluble chromatin fraction increased in a time-dependent manner upon incubation with dexamethasone, indicating the release of histones from chromatin during apoptosis. In the control cells incubated for $6 \mathrm{~h}$ without dexamethasone, only small amounts of histones were also released, which likely reflects spontaneous apoptosis of a small percentage of our cultured cells. ${ }^{18}$

To analyze the amount of apoptosis-specific H2B phosphorylation at Ser14 in the soluble chromatin, a western blot against anti-phosSer14 H2B was conducted (Figure 2b). After $4 \mathrm{~h}$ of dexamethasone treatment, the amount of phosS 14 is significantly increased in the soluble fraction, compared with the insoluble fraction of chromatin (Figure 2b, left). In contrast, other histone modifications such as $\mathrm{H} 4$ acetylation at $\mathrm{K} 8$ are present in both the soluble and insoluble fraction in roughly equivalent amounts (Figure $2 b$, right). These data suggest that histone $\mathrm{H} 2 \mathrm{~B}$ phosphorylation is selectively associated with histone release and internucleosomal DNA degradation during apoptosis.

Intracellular distribution of $\mathbf{S 1 4}$ phosphorylation in apoptotic cells. Next, we evaluated the distribution of the phosS14 in thymocytes by immunofluorescence (Figure 3A). Thymocytes treated with $1 \mu \mathrm{M}$ dexamethasone for $4 \mathrm{~h}$ or left untreated were stained with anti-phosS14 antibody (red) and DAPI (blue). There was an increase in cells that were positive for phosS14 in dexamethasone-treated cells (Figure 3A, 1 and 2). To determine whether the $\mathrm{H} 2 \mathrm{~B}$ phosphorylation is associated with degraded DNA, thymocytes were examined by immunofluorescence of phosS14 (Figure 3B, a), TUNEL

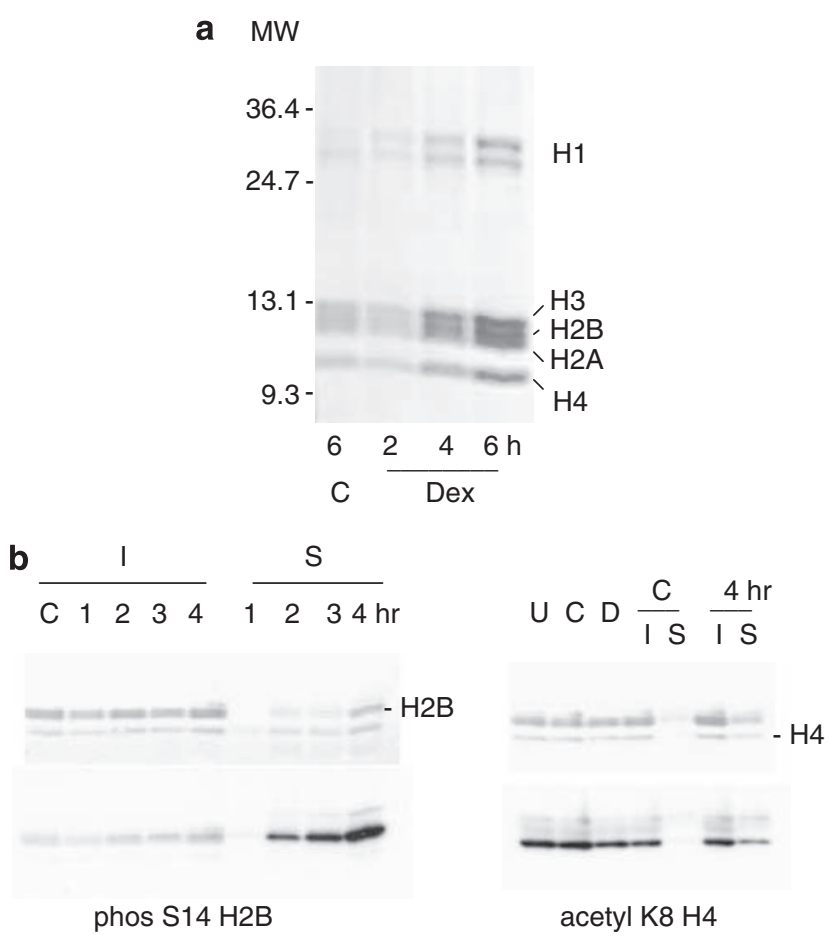

Figure 2 Soluble chromatin contains S14 phosphorylated H2B. (a) Histones were released during apoptotic internucleosomal degradation. Nuclei were isolated from control and dexamethasone-treated cells and incubated with a lysis buffer containing $0.5 \%$ Triton $\mathrm{X}-100$ at $4{ }^{\circ} \mathrm{C}$ Proteins contained in the lysis buffer were analyzed on SDS polyacrylamide gel electrophoresis (PAGE) and stained with $0.1 \%$ Coomassie Brilliant Blue. (b) Thymocytes were incubated at $37^{\circ} \mathrm{C}$ for $1,2,3$ and $4 \mathrm{~h}$ with $1 \mu \mathrm{M}$ dexamethasone. Soluble (S) and insoluble (I) chromatin were isolated from nuclei. Histones were extracted from the chromatin and analyzed on SDS PAGE. Left, Western blots were conducted with an anti-phosphorylation at Serine 14 (phosS14). C; Untreated thymocytes were incubated at $37^{\circ} \mathrm{C}$ and proteins were stained with Ponceau-S. Right, Western blots were conducted with an acK8H4 antibody. U, untreated thymocytes on ice; C, control thymocytes; and D, dexamethasone-treated thymocytes at $37^{\circ} \mathrm{C}$

staining (Figure 3B, b), merge of both (Figure 3B, c) and DAPI (Figure 3B, d). As shown in Figure 3B, cells positive for phosS14 are also TUNEL positive. It is interesting to note that not all TUNEL positive cells stain with phosS14 because the TUNEL reaction occurs in both high molecular weight (HMW) DNA fragments and internucleosomal DNA fragments, whereas phosphorylation of S14H2B occurs primarily in internucleosomal DNA fragments.

Alterations in histone acetylation at K15 within histone H2B. Although no significant difference in the acetylation of histone $\mathrm{H} 4$ at $\mathrm{K} 8$ was observed between soluble and insoluble chromatin (Figure 2b), we were interested in possible changes in the level of acetylation of other sites in histone $\mathrm{H} 2 \mathrm{~B}$. Figure $4 \mathrm{a}$ shows the amino acid sequence and known sites of modifications of $\mathrm{H} 2 \mathrm{~B}$ at the $\mathrm{N}$-terminal tail. There are four major acetylation sites in H2B (K5, K12, K15 and K20). ${ }^{12}$

We focused our studies on lysine 15 because of its proximity to $\mathrm{S14}$. Thus, we examined the level of lysine 15 acetylation and S14 phosphorylation in both soluble 
A
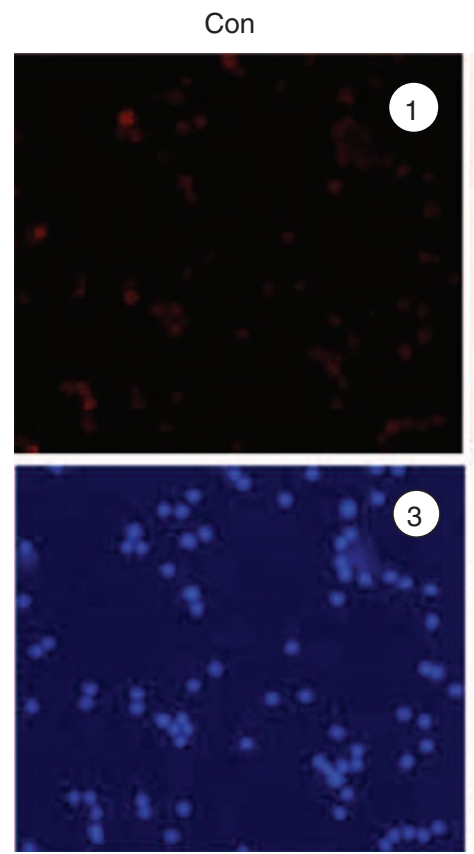

B

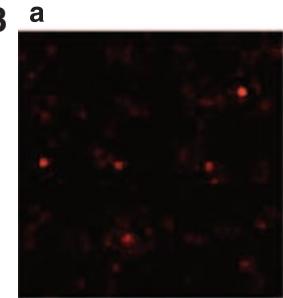

b

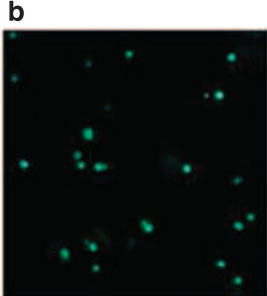

C
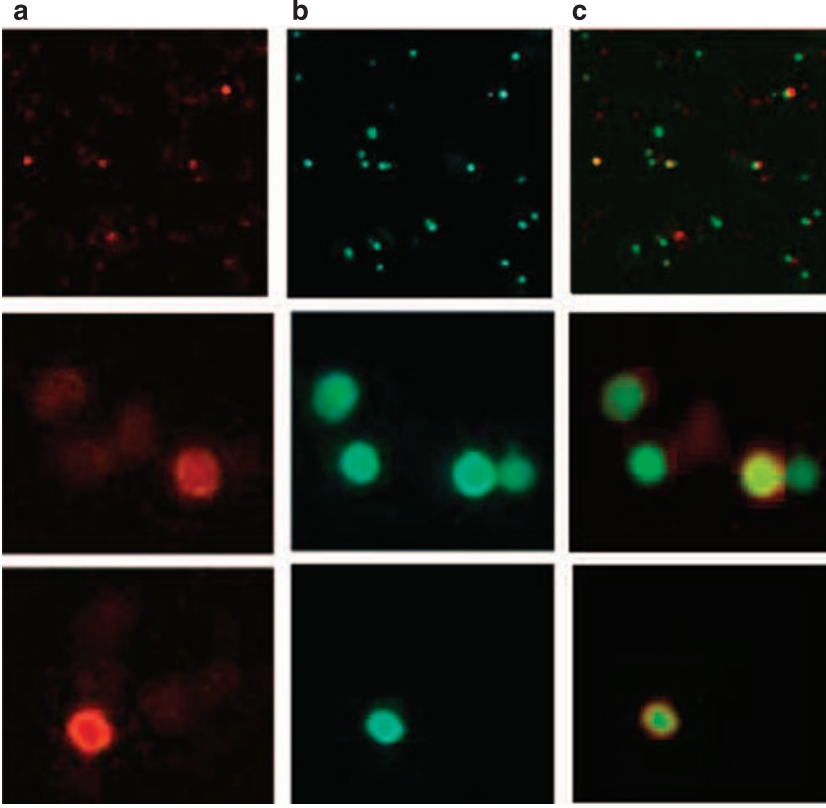

Dex

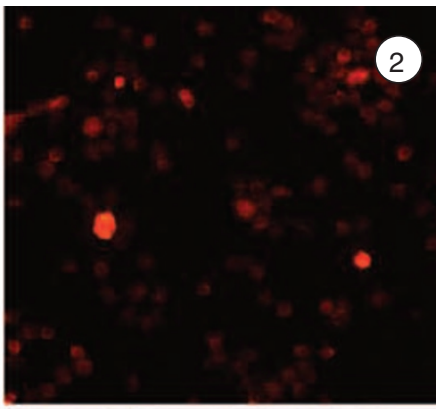

anti phos-

S14H2B

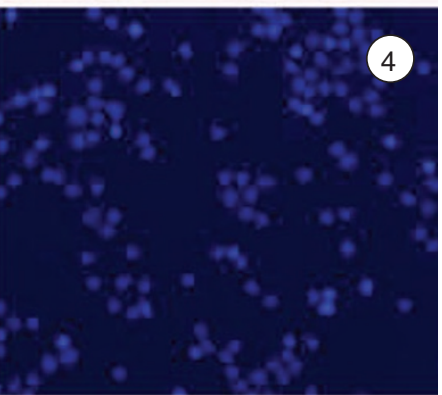

DAPI

Figure 3 Immunofluorescence of S14 phosphorylation and transferase dUTP end-labeling (TUNEL) staining of dexamethasone-treated thymocytes. (A) Thymocytes were fixed with $4 \%$ paraformaldehyde and plated on cover slips and the cells were treated with anti-phosphorylation at Serine 14 (phosS14) and a secondary antibody (Cy3) at $37^{\circ} \mathrm{C}$ for $1 \mathrm{~h}$. Left (1 and 3 ) is control, and right (2 and 4) are dexamethsone-treated cells. 1 and 2 show immunofluorescence of phosS14; 3 and 4, DAPI. (B) Thymocytes were treated as above. (a) Immunofluorescence of phosS14; (b) TUNEL staining; (c) merged; and (d) DAPI. Magnification is $\times 100$ in the four pictures of the top panel, and $\times 800$ in the eight pictures of the middle and the bottom panels

and insoluble chromatin fractions of apoptotic nuclei from glucocorticoid-treated thymocytes. Histones were isolated from soluble and insoluble chromatin obtained from dexamethasone-treated thymocytes. Total chromatin was obtained from untreated (control) cells. Figure $4 \mathrm{~b}$ shows western blots for the acetylation site at K15 (acK15) and the phosphorylation of S14 (phosS14). PhosS14 is more abundant in the soluble than the insoluble fraction from $4 \mathrm{~h}$ dexamethasone-treated thymocytes, and is much greater than the amount in control (Figure 4b, C). In contrast, acK15 was abundant in the control and insoluble fraction but was reduced in the soluble fraction of dexamethasone-treated thymocytes. Therefore, K15 appeared to be highly acetylated in the H2B histones in chromatin from control cells, but partially deacetylated following the induction of apoptosis by dexamethasone. Using synthetic peptide substrates, each 
a

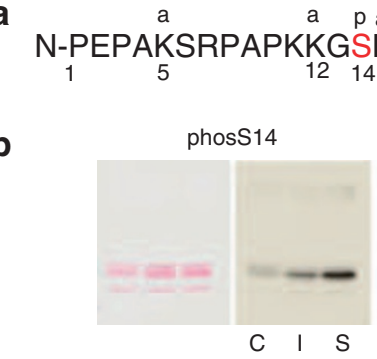

a

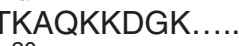

20

acK15

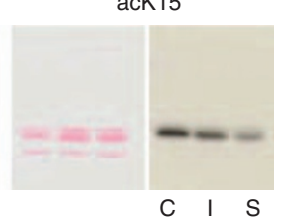

d

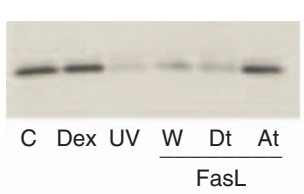

H2B

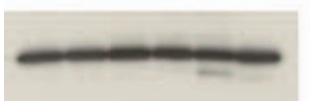

C

C
Con
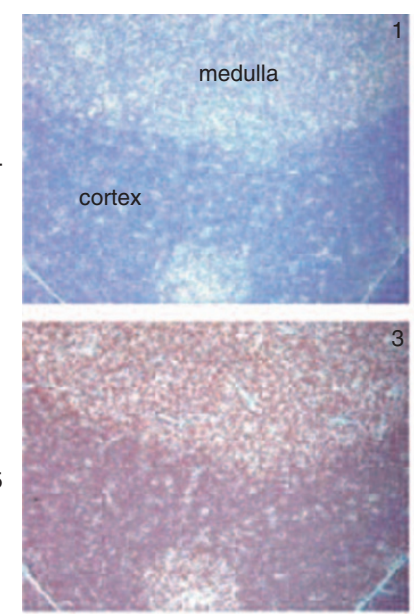

Con

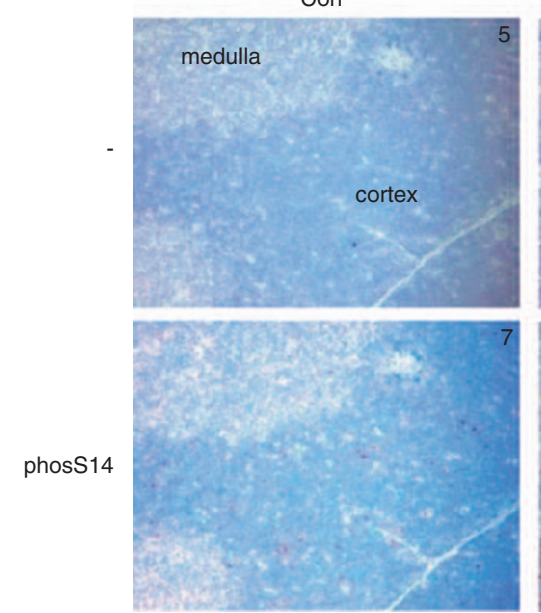

Dex
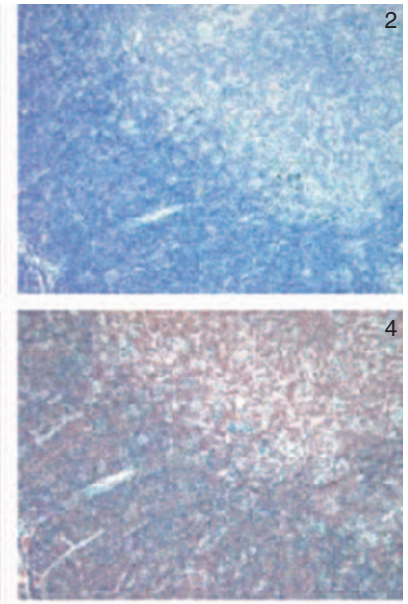

Dex
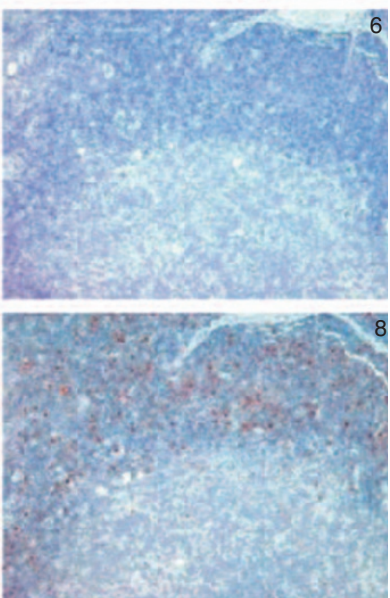

Figure 4 Changes of site-specific histone modifications in the soluble and insoluble chromatin in apoptotic thymocytes. (a) The sites of H2B modifications at the N-terminal tail. Four sites are known to be acetylated at 5,12, 15 and 20th residues of lysine, whereas a phosphorylation occurs at the 14th serine in the middle of an acetylation group. a: acetylation, p: phosphorylation. (b) Acetylation and phosphorylation of H2B in the soluble and insoluble chromatin. Soluble and insoluble chromatins were prepared from dexamethasone-treated thymocytes and histones were extracted. The histones were blotted against antibodies for site-specific modifications (phosphorylation at Serine 14 (phosS14) and acetyl K15) (right panel). Proteins were stained with Ponceau S (left panel). (c) Control chromatin, I: Insoluble chromatin from dexamethasone-treated thymocytes. S: Soluble chromatin from dexamethasone-treated thymocytes. The data shown is representative of an $N=4$. (c) Immunohistochemical analysis of phosS14 and adjacent Lysine 15 (ack15) in thymus tissues. Rat thymus was dissected and the tissues were treated with or without antibodies for histone modifications and stained with horseradish peroxidase. Brown color was observed as a positive reaction of a specific antibody. Pictures from 1 to 4 are a series of immunohistochemical analysis against acK15 and from 5 to 8 are for the analysis of phosS14. 1 and 5: Thymus section from the control animal treated without antibody. 2 and 6: Thymus section from the dexamethasone-treated animal and treated without antibody. 3 and 7: Control section with the antibody. 4 and 8: Dexamethasone section with antibody. (d) A switch of histone modifications between acK15 and phosS14 in H2B of apoptotic HTC cells. Apoptosis was induced in HTC cells by UV-C or Fas ligand. Attached and detached cells were separated by a gentle shaking from glass substratum. Histones were extracted and analyzed by a western blotting against anti-phosS14. C, Control; Dex, dexamethasone; UV, whole cells treated with UV-C; W, whole cells treated with Fas ligand, At and Dt; attached and detached whole cells, respectively from Fas ligand-treated cells. Amount of each sample was normalized by $\mathrm{H} 2 \mathrm{~B}$ detected with an anti-H2B antibody. The data shown is representative of an $N=3$

specific antibody was evaluated for its ability to recognize its respective epitope (acetylated-lysine K15 or phosphorylated S14). Adjacent acetylation and/or phosphorylation had no significant influence on the ability of the antibodies to recognize their appropriate substrates (see supplementary data S1).

To evaluate whether this reciprocal change occurs between deacetylation of $\mathrm{K} 15$ and phosphorylation at S14 during apoptosis of thymocytes in vivo, we injected rats with dexamethasone and after $18 \mathrm{~h}$ the thymus was dissected, sectioned and examined by immunohistochemistry. The control thymus tissue was strongly stained with anti-acK 15 (Figure 4c, 3), whereas staining was less pronounced in dexamethasone-treated tissue (Figure 4c, 4), indicating $\mathrm{H} 2 \mathrm{~B}$ histones are deacetylated at K15 following treatment. In contrast, staining for phosS14 was minimal in the tissue from controls (Figure 4c, 7), but abundant in the thymus of the dexamethasone-treated animals. This staining was concentrated in the thymic cortex area that harbors immature $\mathrm{T}$ cells, which are particularly sensitive to glucocorticoidinduced apoptosis (Figure 4c, 8). Together these data suggest that the switch between $\mathrm{K} 15$ deacetylation and 
Table 1 Summary of results from Figures $4 \mathrm{~b}-$ and HL-60 cells

\begin{tabular}{lllcc}
\hline Cells & Agents & Fractions & phosS14 & acK15 \\
\hline Thymocytes & Con & & - & + \\
& Dex & W & + & - \\
& Dex & Sol & ++ & - \\
\multirow{5}{*}{ HTC cells } & Dex & Ins & - & ++ \\
& Con & & - & + \\
& Dex & & - & + \\
& UV-C & W & + & - \\
& FasL & Dt & + & - \\
& FasL & At & ++ & - \\
HL-60 & FasL & & - & ++ \\
& Con & & - & + \\
& VP-16 & & + & - \\
\hline
\end{tabular}

acK15, adjacent Lysine 15; Con, control; Dex, dexamethasone; phosS14 phosphorylation at Serine 14; Sol and Ins, soluble and insoluble chromatin respectively, from thymocyte nuclei; $\mathrm{W}$, whole chromatin or nuclei. Dt and At, nuclei from detached and attached cells, respectively, isolated from the Fas ligand (FasL)-treated HTC cells. The intensity of the signal of the western blot was represented as - , negligible; +, positive; and ++, intensive. Summary of results from Figure $4 \mathrm{~b}-\mathrm{d}$. Histones were prepared from nuclei or chromatin fractions from cells treated with apoptosis inducing agents as described in the Materials and Methods section and analyzed by western blot against either antiphosS14 or anti-acK15.

S14 phosphorylation also occurs after glucocorticoidtreatment in vivo.

An important question that arises from our studies is whether this epigenetic switch also occurs during apoptosis in other cell types. To address this issue we used HTC cells as a model system. This cell line undergoes apoptosis upon UV-C irradiation or Fas ligand treatment ${ }^{19}$ but not with glucocorticoid treatment, despite the presence of an intact glucocorticoidreceptor signaling system. ${ }^{19}$ After the induction of apoptosis in HTC cells, some cells remained attached to a glass substratum (At), and approximately $30 \%$ of the cells are detached and are floating in the medium (Dt). We observed an increase in the phosphorylation of S14 in the detached UV-C or Fas ligand-treated apoptotic cells (Figure 4d, Dt) compared with the attached cells (Figure 4d, At). In contrast, K15 acetylation was reduced upon induction of apoptosis and release from the substratum, which is a reflection of their state of apoptosis. Similar results were also observed when studying apoptosis of HL-60, a human promyelocytic leukemic cell line, induced by etoposide (data not shown). It is important to note that HTC cells treated with glucocorticoids (Figure $4 \mathrm{~d}$, Dex) show no significant difference compared with control cells in their levels of $\mathrm{K} 15$ acetylation and S14 phosphorylation. The fact that we detected no increase in phosS14 in dexamethasone-treated HTC cells is strong evidence that this epigenetic event is specifically related to apoptosis and not simply a result of glucocorticoid administration, as these cells are known to be glucocorticoid responsive. ${ }^{19}$ Together these data summarized in Table 1 indicate that the switch between deacetylation of $\mathrm{K} 15$ and phosphorylation of S14 in H2B occurs during apoptosis of primary cells as well as established cell lines. Furthermore, this switch appears to be independent of the type of apoptotic stimulus used to initiate the cell death process.

Effect of TSA on the $\mathbf{S 1 4}$ phosphorylation in thymocytes. In an attempt to understand the components of the mechanisms involved in glucocorticoid regulation of epigenetic chromosomal remodeling, we examined the effect of TSA, an inhibitor of histone deacetylases, on the acK15 and phosS14 in thymocytes (Figure 5A). In thymocytes treated with TSA alone, acK15 was markedly increased (Figure 5A, left). In addition, the amount of acK15 remained high in cells treated with TSA plus dexamethsone, whereas phosS14 increased in the dexamethasone-treated thymocytes but remained at control levels in cells treated with dexamethasone plus TSA (Figure 5A, right). Our data suggest that a histone deacetylase is either activated or induced in glucocorticoid-treated thymocytes and consequently acK15 is deacetylated. Thus deacetylation of K15 allows the phosphorylation of S14, further suggesting that they have a reciprocal relationship.

We also examined the DNA degradation and histone release in the soluble chromatin fraction obtained from isolated nuclei (Figure 5B). DNA from cells treated with dexamethasone displays a ladder pattern indicating internucleosomal degradation (lane $\mathrm{C}$ in the Figure 5B left), which is not seen in the two controls (lanes $A$ and $B$ ). However, the cells treated with either TSA alone (lane $\mathrm{D}$ ) or dexamethasone plus TSA showed almost no internucleosomal degradation (lanes $\mathrm{E}$ and $\mathrm{F}$ ). The histone release assay also showed that TSA treatment alone had very little effect on the release of histones (lanes $D$ and $E$ in the Figure $5 B$, right). This lack of internucleosomal degradation under these conditions was not the result of arresting the apoptotic program, as cells treated with TSA alone, Dex alone or TSA plus Dex for $6 \mathrm{~h}$ still underwent apoptosis, as judged by annexin- $\mathrm{V}$ binding and caspase activation (Figure $5 \mathrm{C}$ ). Together these data indicate that deacetylation of histones is crucial to internucleosomal cleavage of DNA during apoptosis.

Phosphorylation assay of synthetic H2B peptides. To gain further insight into the kinases and mechanisms involved in S14 phosphorylation we examined the effect of acetylation of $\mathrm{K} 15$ on the ability of $\mathrm{S} 14$ to be phosphorylated using synthetic $\mathrm{H} 2 \mathrm{~B}$ peptides in vitro. Figure 6 a shows the 16 amino acid peptide substrates of $\mathrm{H} 2 \mathrm{~B}$ from the arginine 7 (R7) to glutamine 22 (Q22). One peptide, acK15, is acetylated at $\mathrm{K} 15$, and one, phosS 14 , is phosphorylated at S14. The control peptide has no modification. These three peptides were tested for their ability to be phosphorylated by $\mathrm{PKC}$, which is a protein kinase known to be responsible for the phosphorylation of the N-terminal H2B. ${ }^{6,9}$ Figure $6 \mathrm{~b}$ indicates the incorporation of ${ }^{32} \mathrm{P}$ into the three different synthetic $\mathrm{H} 2 \mathrm{~B}$ peptides by the PKC phosphorylation assay. The incorporation of ${ }^{32} \mathrm{P}$ into phosS14 peptide was negligible $(1.7 \%)$, as the $\mathrm{S} 14$ site was already phosphorylated. The phosphorylation was suppressed nearly $35 \%$ in the acK 15 peptide. These data suggest that acetylation at K15 can inhibit the phosphorylation of S14 in vitro.

\section{Discussion}

Our results indicate that the phosphorylation of S14 in histone $\mathrm{H} 2 \mathrm{~B}$ occurs during apoptosis of thymocytes and is abundant in the soluble or degraded chromatin fraction of apoptotic cells. In contrast, very little S14 H2B phosphorylation is found 
A
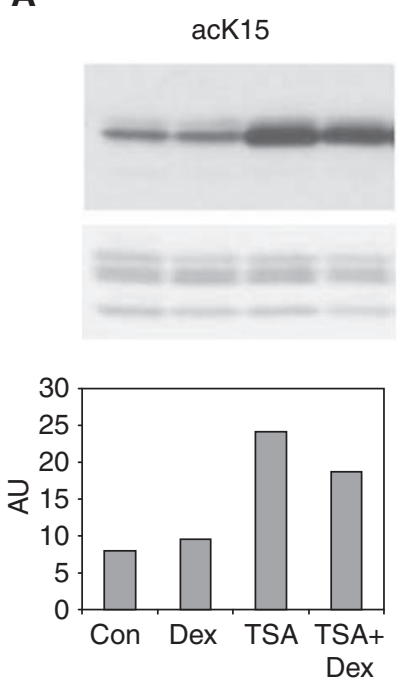

B
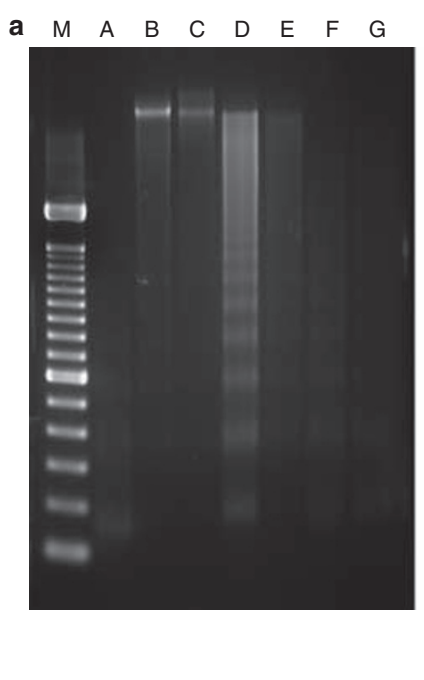

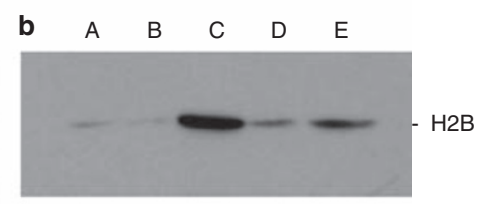

C
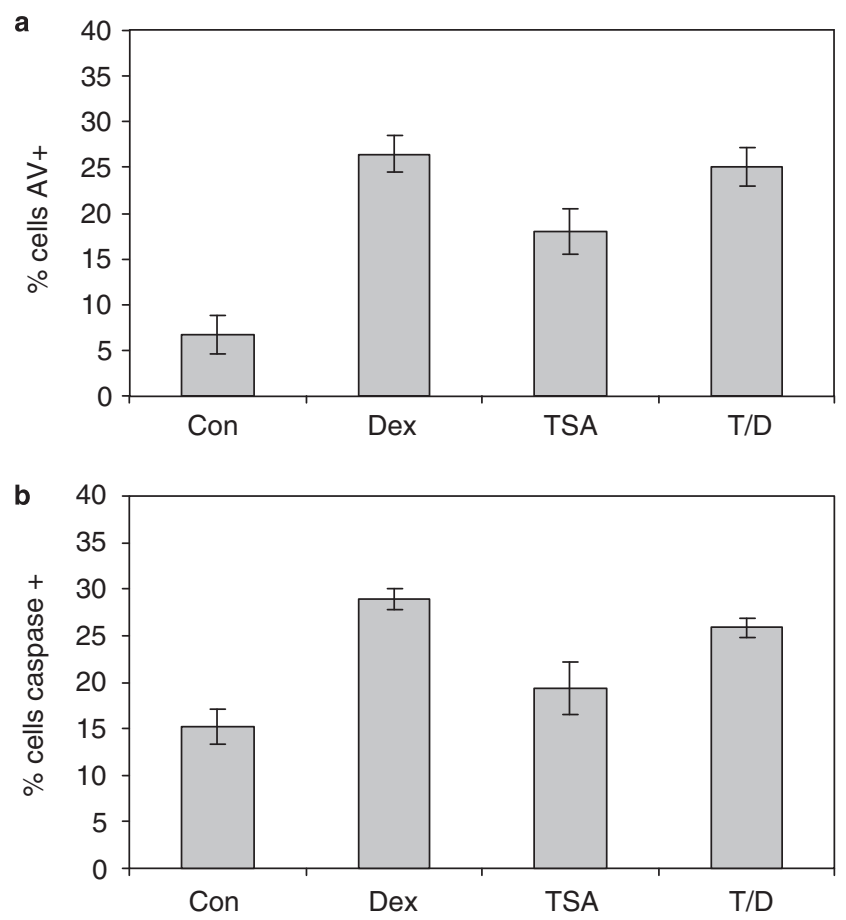

Figure 5 Effect of TSA on histone K15 acetylation, S14 phosphorylation and DNA degradation. (A) Enhancement of K15 and suppression of S14 phosphorylation by a HDAC inhibitor (TSA). Dex, Thymocytes were treated with $1 \mu \mathrm{M}$ dexamethasone; TSA, $1 \mu \mathrm{M} \mathrm{TSA}$ for $3 \mathrm{~h}$, TSA + Dex, pretreated with $1 \mu \mathrm{M}$ TSA for $1 \mathrm{~h}$ and treated with $1 \mu \mathrm{M}$ Dexamethasone for $3 \mathrm{~h}$. Histones were extracted and western blotted against adjacent Lysine 15 (ack15) (left) and phosphorylation at Serine 14 (phosS14) (right). Histones obtained from whole chromatin show a smaller decrease of acK15 in the dexamethasone-treated thymocytes as compared with Figure 4B, which was obtained from soluble chromatin from apoptotic cells. The data shown represents three experiments. (B) TSA prevents Dex-induced DNA degradation and histone release in soluble chromatin. (a) Prevention of DNA degradation. Thymocytes were incubated at $37^{\circ} \mathrm{C}$ for $4 \mathrm{~h}$. Nuclei were isolated. The nuclei were treated with lysis buffer and the soluble chromatin was treated with RNase and proteinase $\mathrm{K}$ and run on $1.8 \%$ agarose gel electrophoresis. M, DNA size marker same as shown in Figure 1C, A, fresh thymocytes. B, control thymocytes incubated without chemicals. C, thymocytes with $10 \mathrm{nM}$ Dex. D, $100 \mathrm{nM}$ Dex. E, $1 \mu \mathrm{M}$ TSA. F, TSA with $10 \mathrm{nM}$ Dex. G, TSA with $100 \mathrm{nM}$ Dex. (b) Prevention of histone release. The soluble chromatin was obtained from thymocytes as described above (a). The soluble chromatin was run on SDS-PAGE gel then analyzed by western blot against anti-H2B. A, fresh thymocytes; B, control thymocytes incubated without chemicals. C, $100 \mathrm{nM}$ Dex; D, $1 \mu \mathrm{M}$ TSA; and E, TSA with $100 \mathrm{nM}$ Dex. (C) TSA does not prevent apoptosis in Dex-treated thymocytes. Isolated rat thymocytes were treated with Dex $1 \mu \mathrm{M}, \mathrm{TSA} 1 \mu \mathrm{M}, \mathrm{TSA}+$ Dex or left untreated for $6 \mathrm{~h}$. Annexin-V binding and caspase 3 -like activity was analyzed by flow cytometry. Dead cells were not used in the analysis. A, Dex, TSA alone and TSA + Dex treatment all caused an increase in the percentage of Annexin-positive cells. B, Dex, TSA alone and TSA + Dex treatment all caused an increase in the percentage of cells with caspase 3-like activity 


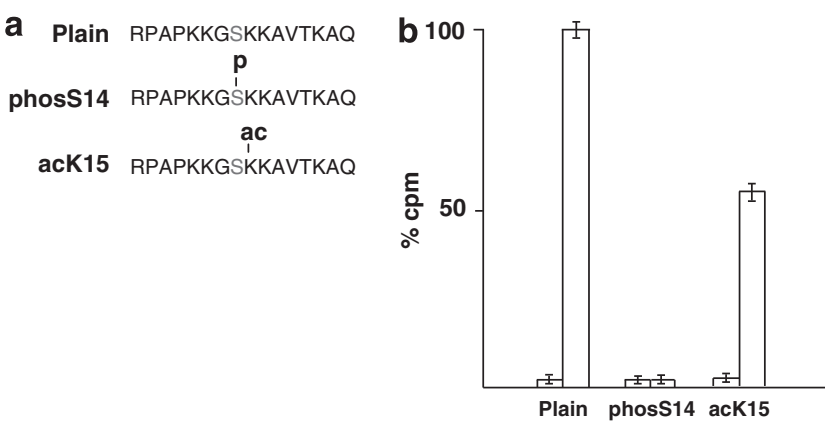

Figure 6 Phosphorylation assay using synthetic H2B peptides. (a) Three kinds of $\mathrm{H} 2 \mathrm{~B}$ peptides were produced (plain, phosphorylation at Serine 14 (phosS14) and adjacent Lysine 15 (acK15)). (b) The PKC-induced incorporation of ${ }^{32} \mathrm{P}$ (c.p.m.) into the modified peptides is shown as percent of unmodified peptides $(100 \%)$. The left columns for each peptide indicate the control value without PKC. Right columns: incorporation of ${ }^{32} \mathrm{P}$ with active $\mathrm{PKC}$ used in the assay system

in the insoluble chromatin fraction of apoptotic or normal control cells. We also show that $\mathrm{K} 15$ is acetylated in normal cells but this modification is greatly diminished during the activation of apoptosis. In addition, we present evidence that K15 deacetylation is necessary to allow S14 H2B phosphorylation and inhibiting this deacetylation step inhibits internucleosomal DNA degradation.

There are two major steps of DNA degradation during apoptosis. One is the production of HMW DNA fragments and the other is internucleosomal DNA degradation. In the early stage of apoptosis, HMW DNA fragments are produced and this is necessary for the subsequent internucleosomal DNA degradation. Our findings indicate that deacetylation of K15 and $\mathrm{S} 14$ phosphorylation associates with internucleosomal DNA degradation. Other histone modifications are known to occur during apoptosis such as $\mathrm{H} 4$ acetylation, ${ }^{20} \mathrm{H} 4$ trimethylation, ${ }^{21} \mathrm{H} 3$ methylation and phosphorylation ${ }^{22,23}$ and $\mathrm{H} 1$ dephosphorylation. ${ }^{24}$ Together with $\mathrm{H} 2 \mathrm{~B}$ phosphorylation, these histone modifications may occur in the same chromatin domain and may work cooperatively.

Our data also reveal that $\mathrm{K} 15$ is acetylated in normal rat thymocytes, but during the activation of apoptosis this acetylation is decreased as the phosphorylation of $\mathrm{S} 14$ is increased. It has been reported that the $\mathrm{N}$-terminal tail of $\mathrm{H} 2 \mathrm{~B}$ itself is crucial for chromatin condensation. ${ }^{25}$ Moreover, the $\mathrm{H} 2 \mathrm{~B}$ acetylation at the $\mathrm{N}$-terminal end is important to maintain a stable structure of $\mathrm{H} 2 \mathrm{~A}-\mathrm{H} 2 \mathrm{~B}$ dimers in the nucleosome. ${ }^{26,27}$ As the $\mathrm{N}$-terminal domain of $\mathrm{H} 2 \mathrm{~B}$ including the $\mathrm{S} 14$ site exists outside the nucleosome structure, ${ }^{28}$ it could be susceptible to modification by phosphatases or kinases if left unprotected. Deacetylation of $\mathrm{K} 15$ seems to be necessary for the phosphorylation of S14, whereas acetylation of K15 may prevent the S14 phosphorylation. These observations suggest that acetylation of $\mathrm{K} 15$ in normal cells could be functionally important in protecting cells from irreversible apoptotic DNA degradation. In this regard we previously demonstrated in HL-60 cells that one of the kinases responsible for the $\mathrm{S} 14$ phosphorylation is Mst-1, although PKC- $\delta$ has also been reported to phosphorylate this site in immune cells. ${ }^{8}$ Mst- 1 is activated by caspase- $3^{8}$ and can then translocate from cytoplasm to nucleus. ${ }^{29,30}$
This study demonstrates an interesting epigenetic switch between two amino-acid modifications in the $\mathrm{N}$-terminus of H2B that occurs during apoptosis in mammalian cells. A similar relationship has been reported for the phosphorylation at Ser10 interacting with the adjacent $\mathrm{K} 9$ methylation sites in $\mathrm{H} 3{ }^{31}$ Intriguingly, we have shown that the H2B phosphorylation could be a prerequisite for apoptosis execution in various mammalian cells resulting from several apoptotic agents. ${ }^{6,9}$ Recently, it has been shown that H2B phosphorylation occurs during oxidative stress in yeast at Ser10, which is homologous to $\mathrm{S} 14$ in vertebrates. ${ }^{13}$ These authors suggest a specific deacetylation at $\mathrm{K} 11$ and phosphorylation at $\mathrm{S} 10$ at the histone $\mathrm{H} 2 \mathrm{~B}$ tail required for cell death in yeast. ${ }^{14}$

There are numerous reports that general histone deacetylase inhibition causes apoptosis. ${ }^{32}$ Indeed in our studies using the non-specific histone deacetylase inhibitor TSA we show that it alone can cause cell death. However, we also demonstrate that TSA prevented internucleosomal DNA degradation induced by glucocorticoids, as well as hyperacetylating $\mathrm{K} 15 \mathrm{H} 2 \mathrm{~B}$ and inhibiting $\mathrm{S} 14 \mathrm{H} 2 \mathrm{~B}$ phosphorylation. Thus, during apoptosis $\mathrm{K} 15$ is likely deacetylated by endogenous HDAC's in a more specific manner.

Previously, we have shown that CAD (-/-) DT40 chicken cells treated with VP16 had a pSer14 positive reaction that could be detected by immunocytochemistry. ${ }^{9}$ Within cell nuclei, the pSer14 reaction was co-localized with DAPI dense chromatin suggesting that pSer14 is associated with chromatin condensation rather than caspase-dependent internucleosomal DNA fragmentation. In the current studies using primary thymocytes from adrenalectomized rats we observed that phosS14 H2B during thymocyte apoptosis seemed mainly localized at the periphery of nuclei which yet does not show clear condensation (Figure 1B). This difference in the structure of chromatin and the localization of phosS14 may be a reflection of cell type or the apoptotic agent used for the induction of cell death.

The epigenetic switch between the two-histone modifications in $\mathrm{H} 2 \mathrm{~B}$ could induce a change of nucleosome structure in the $\mathrm{H} 2 \mathrm{~B}$ tail at specific regions of chromatin, and the remodeling of that chromatin domain would facilitate the accessibility for endonucleases. These findings are important for the structural analysis of nucleosomes during apoptosis, especially the interaction between covalent histone modification and internucleosomal DNA degradation.

\section{Materials and Methods}

Isolation of thymocytes and induction of apoptosis. Male Sprague Dawley rats (2-3 month of age) were used and the animals were bilaterally adrenalectomized by the provider at least 5 days before use. They were maintained under controlled conditions of temperature $\left(25^{\circ} \mathrm{C}\right)$ and lighting, and allowed free access to food and $0.85 \%$ saline. All experimental protocols were approved by the animal review committee at NIEHS/NIH and were carried out in accordance with the guidelines set forth in the NIH Guide for the Care and Use of Laboratory Animals published by the USPHS. Animals were killed by decapitation and the thymus was surgically removed. The thymus was minced with scissors in RPMI 1460 medium containing $10 \%$ heat-inactivated fetal calf serum, $2 \mathrm{mM}$ glutamine, $75 \mathrm{U} / \mathrm{ml}$ streptomycin, and $100 \mathrm{U} / \mathrm{ml}$ penicillin at room temperature. The minced tissues were placed in a tube and shaken by hand until free thymocytes were released.

For the isolation of nuclei, the thymocytes were washed once in isolation buffer (20 mM HEPES pH 7.5, $10 \mathrm{mM} \mathrm{KCl,} 3 \mathrm{mM} \mathrm{MgCl}_{2}, 0.25 \mathrm{M}$ sucrose, $1 \mathrm{mM}$ DTT and $1 \mathrm{mM}$ PMSF). The cells were re-suspended in isolation buffer, and treated with 
$0.25 \% \mathrm{NP}-40$ in buffer for $10 \mathrm{~min}$ at $4^{\circ} \mathrm{C}$ The buffer containing $1.2 \mathrm{M}$ sucrose was underlayed as a cushion and centrifuged. The nuclear pellet was washed once in isolation buffer.

Thymocytes, $2 \times 10^{6}$ cells/ml, were incubated in RPMl 1640 medium at $37^{\circ} \mathrm{C}$ $5 \% \mathrm{CO}_{2}$ atmosphere with $1 \mu \mathrm{M}$ dexamethasone for various time points depending on experiments. The cells were harvested at room temperature and were washed twice with PBS solution. For the studies using a histone deacetylase inhibitor, cells were pre-treated for $1 \mathrm{~h}$ with $1 \mu \mathrm{M}$ of TSA, ${ }^{33} \mathrm{HTC}$ cells, a rat hepatoma cell line, were cultured in DMEM-H medium containing $5 \%$ heat-inactivated fetal calf serum, $2 \mathrm{mM}$ glutamine, $75 \mathrm{U} / \mathrm{ml}$ streptomycin and $100 \mathrm{U} / \mathrm{ml}$ penicillin at $37^{\circ} \mathrm{C} 5 \% \mathrm{CO}_{2}$ atmosphere. ${ }^{19}$ For the induction of apoptosis in this cell line, the HTC cells were irradiated with $90 \mathrm{~mJ} / \mathrm{cm}^{2}$ of UV-C and assayed $24 \mathrm{~h}$ later or treated with $50 \mathrm{ng} / \mathrm{ml}$ of Fas ligand (Kamiya Biomedical, Seattle, WA, USA) for $18 \mathrm{~h}$. HL-60, a human promyelocytic leukemia cell line, was cultured in RPMl 1640 medium at $37^{\circ} \mathrm{C} 5 \%$ $\mathrm{CO}_{2}$ atmosphere. For the induction of apoptosis of HL-60 cells, the cells were treated with $20 \mu \mathrm{g} / \mathrm{ml}$ of VP-16 (etoposide) for $16 \mathrm{~h}^{6}$

Flow cytometric analysis of apoptotic thymocytes. The thymocytes $\left(1 \times 10^{6}\right)$ treated with dexamethasone as described above were analyzed by flow cytometry using a Becton Dickinson FACSort. A change in cell size was determined by measuring the cells ability to scatter light in the forward direction. An increase or decrease in forward light scatter indicates an increase or decrease in cell size, respectively. Cell density or granularity is determined by side-scattered light. Data shown are contour plots of forward-scattered light versus side-scattered light. Propidium iodide $(10 \mathrm{mg} / \mathrm{ml})$ was added as a vital dye to gate out those cells which had lost membrane integrity.

Annexin-V and Caspatag assay. Thymocytes were isolated as described and treated with either dexamethasone $1 \mu \mathrm{M}$, TSA $1 \mu \mathrm{M}$, or TSA plus Dex (TSA pretreatment), or left untreated for $6 \mathrm{~h}$. The cells were then stained with Annexin-V and propidium iodide using manufacturers protocol (Trevigen, Gaithersburg, MD, USA). Briefly, $1 \times 10^{6}$ cells are incubated with fluorescently tagged Annexin-V and then analyzed by flow cytometry using a FACSort (Becton-Dickinson, San Jose, CA, USA). For determining caspase activity, cells were incubated with a fluorescent caspase 3 substrate following the manufacturer's protocol (Caspatag, Millipore, Billerica, MA, USA) and then analyzed by flow cytometry. Propidium iodide (10 mg/ $\mathrm{ml}$ ) was added as a vital dye to gate out those cells which had lost membrane integrity.

Electron microscopy. For electron microscopy, thymocytes treated with $1 \mu \mathrm{M}$ dexamethasone in vitro for $4 \mathrm{~h}$ were harvested and gently centrifuged and washed twice with PBS. The pellets were fixed in a modified Karnovsky buffer $(2.0 \%$ paraformaldehyde/ $2.5 \%$ glutaraldehyde in $0.1 \mathrm{M}$ sodium cacodylate buffer, $\mathrm{pH} 7.4$ ). The materials were post-fixed with $2 \% \mathrm{OsO}_{4}$ for $1 \mathrm{~h}$. The cells were passed through a series of alcohol washes for dehydration and then embedded in Epon. Ultra thin sections were mounted and stained with $5 \%$ uranyl acetate followed by Reynold's lead citrate and observed on a JEOL 100S transmission electron microscope.

Isolation of soluble chromatin and DNA analysis. For the preparation of soluble chromatin from apoptotic cells, nuclei isolated from apoptotic cells were incubated with a lysis buffer (10 mM Tris-HCl, pH.7.4, $10 \mathrm{mM}$ EDTA and 0.5\% Triton $\mathrm{X}-100$ ) for $10 \mathrm{~min}$ at $4^{\circ} \mathrm{C}$ The nuclei were centrifuged and the supernatant collected as soluble chromatin (approximately $5 \%$ of total chromatin from apoptotic cells) and the pellet as insoluble chromatin. For the analysis of DNA degradation, cells were isolated and harvested after the incubation at $37^{\circ} \mathrm{C}$ with $1 \mu \mathrm{M}$ dexamethasone and were treated with $1 \mathrm{mg} / \mathrm{ml}$ of DNase-free RNase for $1 \mathrm{~h}$ at $37^{\circ} \mathrm{C}$ and then $400 \mu \mathrm{g} / \mathrm{ml}$ proteinase $\mathrm{K}$ was added with overnight incubation at $37^{\circ} \mathrm{C}$ DNA ( 1 or $2 \mu \mathrm{g}$ ) was run on $1.8 \%$ agarose gels at 100 volts with a size marker of DNA ( 100 base pairs of DNA ladder, Ready-Load Invitrogen, Carlsbad, CA, USA). The DNA was stained with $0.25 \mu \mathrm{g} / \mathrm{ml}$ of ethidium bromide and photographed with UV-transilluminator.

\footnotetext{
Western blotting, immuno-fluorescent analysis and transferase dUTP end-labeling (TUNEL) assay. Histones were prepared as described previously ${ }^{34}$ and the proteins $(5 \mu \mathrm{g})$ were analyzed. For western blot analysis, antibodies of site-specific histone H2B modifications were purchased from Upstate (now Millipore). Methods for immuno-fluorescent analysis were described earlier. ${ }^{9}$ Briefly, dexamethasone treated thymocytes $\left(1 \times 10^{4}\right)$ were fixed with $4 \%$ paraformaldehyde for $10 \mathrm{~min}$. After washing with PBS, the cells were plated on cover slips. The cells were dried at $4^{\circ} \mathrm{C}$ and permeabilized with $0.2 \%$ Triton $\mathrm{X}-100$.
}

The cells were equilibrated with $2 \%$ goat serum in PBS and were incubated with anti-phosS 14 antibody at $37^{\circ} \mathrm{C}$ for $1 \mathrm{~h}$ in a moisture chamber. After washing, the cells were further treated with Cy3. The nuclei were counterstained with DAPI. For the detection of cleaved DNA in nuclei, a fluorescent terminal deoxynucleotidyl TUNEL assay was conducted (Promega, Madison, WI, USA). Images were taken by phase contrast microscopy (Olympus, IX70).

Immunohistochemical analysis of histone H2B phosphorylation and acetylation in thymus tissues. Adrenalectomized rats were injected with dexamethasone ( $1 \mathrm{mg}$ in $0.9 \%$ saline per animal) intra-peritoneally. The control animals were injected with a same amount of saline only. After $18 \mathrm{~h}$, the animals were decapitated and the thymus was surgically removed and fixed in $4 \%$ paraformaldehyde. Thin sections of the thymus tissue were obtained and placed on a glass and further processed for immuno-histochemistry. The slides were treated with anti-phosS14 or anti-acetyl K15 antibodies and conjugated with an anti-rabbit IgG horseradish peroxidase (HRP) from donkey as a secondary antibody. For each experiment, sections stained without primary antibody were examined simultaneously as a control.

Phosphorylation of synthetic H2B peptides. Three H2B peptides were synthesized, containing 16 amino acid residues from arginine 7 (R7) to glutamine 22 (Q22) (AnaSpec, Fremont, CA, USA). Two peptides were modified with acetylation at K15 or phosphorylation at $S 14$. One was a non-modified peptide as shown in the Figure 4A. They were assayed with a PKC phosphorylation assay (UpstateMillipore) in a reaction mixture $(30 \mu l)$ containing $\mathrm{Ca}^{2+}$ and $\mathrm{Mg}^{2+}$ ions, lipid activator, PKA/CaM inhibitors, $1 \mu \mathrm{M}$ TSA, $100 \mu \mathrm{M}$ synthetic peptides, [32P- $\gamma$ ]ATP and active PKC enzyme and buffer. The mixtures were incubated at $30^{\circ} \mathrm{C}$ for $10 \mathrm{~min}$. The ${ }^{32} \mathrm{P}$-labeled peptides were trapped with a p81 filter (Millipore), and washed once with acetone. Radioactivity was assessed with a scintillation counter.

Antibody recognition of epitopes when adjacent residues are modified. A double modified peptide with phosphorylation and acetylation at serine 14 and lysine 15 was developed, phosS14/acK15: RPAPKKGS(p)K(ac)KAVTKAQ, and synthetic peptides described above were loaded on a nitrocellulose membrane using Dot Dolt-loading apparatus (Biorad, Hercules, CA, USA). The amount of peptides ranged from 0.08 to $20 \mu \mathrm{g}$ per $200 \mu \mathrm{l}$ TBS solution per well. The peptides on the membrane were washed twice with $200 \mu$ l of Tween-TBS (TTBS) and were processed similarly to a western blot method. After blocking with $5 \%$ milk for $1 \mathrm{~h}$, the membrane was treated with two antibodies (phosS14 and ack15) at 1 out of 800 and 1 out of 1000 , respectively. After washing the membrane with TTBS, the membrane was treated with secondary antibody ( 1 out of 2000 of HRP) for 40 min. Pictures of a peroxidase reaction in dots were taken by Las 3000 MINI (FUJIFILM, Valhalla, NY, USA). For ninhydrin staining, $0.2 \mu \mathrm{g}$ of each $\mathrm{H} 2 \mathrm{~B}$ peptide was spotted on a Whatman $3 \mathrm{MM}$ paper and sprayed with $2 \%$ Ninhydrin Spray Reagent (Sigma Aldrich, St Louis, MO, USA). The paper was heated in an oven at $120^{\circ} \mathrm{C}$ for $10 \mathrm{~min}$.

\section{Conflict of interest}

The authors declare no conflict of interest.

Acknowledgements. We thank Tiwanda Marsh for the assistance in histochemical analysis. We thank the members of our laboratory for useful discussion. This research was supported by grant number 1Z01ES090057 of the Intramural Research Program of the NIEHS, NIH.

1. Kornberg RD, Lorch Y. Twenty-five years of the nucleosome, fundamental particle of the eukaryote chromosome. Cell 1999; 98: 285-294.

2. Isenberg I. Histones. Ann Rev Biochem 1979; 48: 159-191.

3. Strahl BD, Allis CD. The language of covalent histone modifications. Nature 2000; 403: 41-45.

4. Wyllie AH, Morris RG, Smith AL, Dunlop D. Chromatin cleavage in apoptosis: association with condensed chromatin morphology and dependence on macromolecular synthesis. J Pathol 1984; 142: 67-77.

5. Compton MM. A biochemical hallmark of apoptosis: internucleosomal degradation of the genome. Cancer Metastasis Rev 1992; 11: 105-119.

6. Ajiro K. Histone $\mathrm{H} 2 \mathrm{~B}$ phosphorylation in mammalian apoptotic cells: an association with DNA fragmentation. J Biol Chem 2000; 275: 439-443. 
7. Ajiro K, Th'ng J, Yau J, Nishi Y. Isolation and characterization of mammalian cells that are undergoing apoptosis by a bovine serum albumin density gradient. Anal Biochem 2004; 332: 226-233.

8. Hu Y, Liu Z, Yang SJ, Ye K. Acinus-provoked protein kinase C delta isoform activation is essential for apoptotic chromatin condensation. Cell Death Differ 2007; 14: 2035-2046.

9. Cheung WL, Ajiro K, Samejima K, Kloc M, Cheung P, Mizzen CA et al. Apoptotic phosphorylation of histone $\mathrm{H} 2 \mathrm{~B}$ is mediated by mammalian sterile twenty kinase. Cell 2003; 113: 507-517.

10. Mecklenbrauker I, Kalled SL, Leitges M, Mackay F, Tarakhovsky A. Regulation of B-cell survival by BAFF-dependent PKCdelta-mediated nuclear signalling. Nature 2004; 431: 456-461.

11. Fernandez-Capetillo $O$, Allis $C D$, Nussenzweig A. Phosphorylation of histone $\mathrm{H} 2 \mathrm{~B}$ at DNA double-strand breaks. J Exp Med 2004; 199: 1671-1677.

12. Thorne AW, Kmiciek D, Mitchelson K, Sautiere P, Crane-Robinson C. Patterns of histone acetylation. Eur J Biochem 1990; 193: 701-713.

13. Ahn SH, Cheung WL, Hsu JY, Diaz RL, Smith MM, Allis CD. Sterile 20 kinase phosphorylates histone $\mathrm{H} 2 \mathrm{~B}$ at serine 10 during hydrogen peroxide-induced apoptosis in $S$ cerevisiae. Cell 2005; 120: 25-36.

14. Ahn SH, Diaz RL, Grunstein M, Allis CD. Histone H2B deacetylation at lysine 11 is required for yeast apoptosis induced by phosphorylation of $\mathrm{H} 2 \mathrm{~B}$ at serine 10. Mol Cell 2006; 24: 211-220.

15. Wyllie AH. Glucocorticoid-induced thymocyte apoptosis is associated with endogenous endonuclease activation. Nature 1980; 284: 555-556.

16. Mann CL, Hughes Jr FM, Cidlowski JA. Delineation of the signaling pathways involved in glucocorticoid-induced and spontaneous apoptosis of rat thymocytes. Endocrinology 2000; 141: $528-538$.

17. Ajiro K, Bortner CA, Westmoreland J, Cidlowski JA. An endogenous calcium-dependent caspase-independent intranuclear degradation pathway in thymocyte nuclei: Antagonism by physiological concentrations of $\mathrm{K}^{+}$ions. Exp Cell Res 2008; 314: 1237-1249.

18. Tadakuma $\mathrm{T}$, Kizaki $\mathrm{H}$, Odaka $\mathrm{C}$, Kubota $\mathrm{R}$, Ishimura $\mathrm{Y}$, Yagita $\mathrm{H}$ et al. CD4+ CD8+ thymocytes are susceptible to DNA fragmentation induced by phorbol ester, calcium ionophore and anti-CD3 antibody. Eur J Immunol 1990; 20: 779-784.

19. Scoltock AB, Heimlich G, Cidlowski JA. Glucocorticoids inhibit the apoptotic actions of UV$\mathrm{C}$ but not Fas ligand in hepatoma cells: direct evidence for a critical role of $\mathrm{Bcl}-\mathrm{x}(\mathrm{L})$. Cell Death Differ 2007; 14: 840-850.

20. Allera C, Lazzarini G, Patrone E, Alberti I, Barboro P, Sanna P et al. The condensation of chromatin in apoptotic thymocytes shows a specific structural change. J Biol Chem 1997; 272: $10817-10822$.
21. Boix-Chornet M, Fraga MF, Villar-Garea A, Caballero R, Espada J, Nunez A et al. Release of hypoacetylated and trimethylated histone $\mathrm{H} 4$ is an epigenetic marker of early apoptosis. $J$ Biol Chem 2006; 281: 13540-13547.

22. Hurd PJ, Bannister AJ, Halls K, Dawson MA, Vermeulen M, Olsen JV et al. Phosphorylation of histone H3 Thr-45 is linked to apoptosis. J Biol Chem 2009; 284: 16575-16583.

23. Cheng MF, Lee $\mathrm{CH}$, Hsia KT, Huang GS, Lee HS. Methylation of histone H3 lysine 27 associated with apoptosis in osteosarcoma cells induced by staurosporine. Histol Histopathol 2009; 24: 1105-1111.

24. Kratzmeier M, Albig W, Hanecke K, Doenecke D. Rapid dephosphorylation of $\mathrm{H} 1$ histones after apoptosis induction. J Biol Chem 2000; 275: 30478-30486.

25. de la Barre AE, Angelov D, Molla A, Dimitrov S. The N-terminus of histone H2B, but not that of histone $\mathrm{H} 3$ or its phosphorylation, is essential for chromosome condensation. EMBO $J$ 2001; 20: 6383-6393.

26. Brower-Toland B, Wacker DA, Fulbright RM, Lis JT, Kraus WL, Wang MD. Specific contributions of histone tails and their acetylation to the mechanical stability of nucleosomes. J Mol Biol 2005; 346: 135-146.

27. Wunsch $A$, Jackson $V$. Histone release during transcription: acetylation stabilizes the interaction of the $\mathrm{H} 2 \mathrm{~A}-\mathrm{H} 2 \mathrm{~B}$ dimer with the $\mathrm{H} 3-\mathrm{H} 4$ tetramer in nucleosomes that are on highly positively coiled DNA. Biochemistry 2005; 44: 16351-16364.

28. Luger K, Mader AW, Richmond RK, Sargent DF, Richmond TJ. Crystal structure of the nucleosome core particle at 2.8 A resolution. Nature 1997; 389: 251-260.

29. Ura S, Masuyama N, Graves JD, Gotoh Y. Caspase cleavage of MST1 promotes nuclear translocation and chromatin condensation. Proc Natl Acad Sci USA 2001; 98: 10148-10153.

30. Graves JD, Draves KE, Gotoh Y, Krebs EG, Clark EA. Both phosphorylation and caspasemediated cleavage contribute to regulation of the Ste20-like protein kinase Mst1 during CD95/Fas-induced apoptosis. J Biol Chem 2001; 276: 14909-14915.

31. Rea S, Eisenhaber F, O'Carroll D, Strahl BD, Sun ZW, Schmid M et al. Regulation of chromatin structure by site-specific histone $\mathrm{H} 3$ methyltransferases. Nature 2000; 406 : 593-599.

32. Carew JS, Giles FJ, Nawrocki ST. Histone deacetylase inhibitors: mechanisms of cell death and promise in combination cancer therapy. Cancer Lett 2008; 269: 7-17.

33. Yoshida M, Horinouchi S. Trichostatin and leptomycin. Inhibition of histone deacetylation and signal-dependent nuclear export. Ann N Y Acad Sci 1999; 886: 23-36.

34. Ajiro K, Borun TW, Shulman SD, McFadden GM, Cohen LH. Comparison of the structures of human histone $1 \mathrm{~A}$ and $1 \mathrm{~B}$ and their intramolecular phosphorylation sites during the $\mathrm{HeLa}$ S-3 cell cycle. Biochemistry 1981; 17: 1454-1464.

\section{Supplementary Information accompanies the paper on Cell Death and Differentiation website (http://www.nature.com/cdd)}

